DOI: $10.17516 / 1999-494 X-0300$

УДК 621.891:001.891.573

\title{
Numerical Modeling of Tribological Characteristics of Fibrous Polymer Composite Materials
}

\author{
Denis D. Palkin* and Andrey A. Chekalkin \\ Perm National Research Polytechnic University \\ Perm, Russian Federation
}

Received 03.12.2020, received in revised form 15.02.2021, accepted 21.03.2021

\begin{abstract}
The paper presents a numerical simulation of the contact interaction of fibrous polymer composite materials in a finite element ANSYS package and studies the friction coefficients for cells with wear of $0 \%, 25 \%, 50 \%$ and $75 \%$. To predict the coefficient of friction of composites it was proposed to use the method of mechanics of composite materials - the method of local approximation. With the help of numerical simulation, the fields of distribution of normal stresses and contact stresses in the contact zone were obtained and the corresponding conclusions were drawn.
\end{abstract}

Keywords: friction coefficient, fibrous composite materials, polymer composite materials, numerical modeling, contact stresses, local approximation method, unidirectional composite materials, tetragonal structure, dry friction, tribological characteristics.

\section{Численное моделирование коэффициентов трения}

\section{однонаправленных волокнистых композитов}

\section{тетрагональной структуры}

\author{
Д.Д. Палкин, А.А. Чекалкин \\ Пермский национальный исследовательский \\ политехнический университет \\ Российская Федерация, Пермь
}

Аннотация. В работе представлено численное моделирование контактного взаимодействия волокнистых полимерных композиционных материалов в конечно-элементном пакете ANSYS и исследованы коэффициенты трения для ячеек с износом 0, 25, 50 и 75 \%. Для прогнозирования

(C) Siberian Federal University. All rights reserved

This work is licensed under a Creative Commons Attribution-Non Commercial 4.0 International License (CC BY-NC 4.0).

* Corresponding author E-mail address: 1lorddark3@gmail.com 
коэффициента трения композитов было предложено использовать метод механики композиционных материалов - метод локального приближения. С помощью численного моделирования получены поля распределения нормальных напряжений и контактных напряжений в зоне контакта и сделаны соответствующие выводы.

Ключевые слова: коэффициент трения, волокнистые композиционные материалы, полимерные композиционные материалы, численное моделирование, контактные напряжения, метод локального приближения, однонаправленные композиционные материалы, тетрагональная структура, сухое трение, трибологические характеристики.

Цитирование: Палкин, Д.Д. Численное моделирование коэффициентов трения однонаправленных волокнистых композитов тетрагональной структуры / Д.Д. Палкин, А.А. Чекалкин // Журн. Сиб. федер. ун-та. Техника и технологии, 2021, 14(2). C. 198-206. DOI: 10.17516/1999-494X-0300

\section{Introduction}

For the development of modern engineering to develop new materials with improved properties of materials considering a number of factors and their purpose. In the case of tribological materials in the friction units of structures, it is necessary to know their tribological characteristics of the materials, for example, the coefficient of friction of the material.

For the development and creation of composite materials and the calculation of structures from them, corresponding theoretical knowledge is required, based on the mechanics of homogeneous bodies and considering their structural heterogeneity. For this, mathematical models and methods for solving problems in the mechanics of structurally heterogeneous bodies have been developed. Methods mechanics predict properties of composite materials of different structures. In various works, the forecasting of elastic, elastic-plastic and viscoelastic properties, stiffness and strength properties, fatigue life characteristics and other characteristics of composite materials is displayed [1-3]. Thus, they are acceptable for predicting any properties of materials that are used in structures for various purposes. Therefore, the method of mechanics of composite materials can be used to predict the tribological characteristics of the material.

In the case of the application of tribotechnical constructions, the materials must have high tribological characteristics. When using composite materials in friction nodes, their tribological characteristics are not real material properties, but depend on the system in which these composite materials should work [4-7]. Modern works are devoted to the experimental study of the tribological characteristics of materials. In an experimental study, it is necessary to consider the geometry of the contact pair, the kinematics of the movement of the tribocouple, the presence and type of lubricant, etc. The study of the tribological characteristics of composite materials must consider many factors that affect them.

The article discusses a model of contact interaction of unidirectional fiber composites of fibers in order to study the tribological characteristics of the coefficient of friction of the material. The subject of study of this work is to study the coefficient of friction of a unidirectional fiber composite from a position of the mechanics of composite materials. The object of the study are unidirectional fiberglass and carbon composites, which constitute the polymeric material reinforced with continuous fibers in one direction.

\section{Materials and Methods}

One of the main characteristics of tribological material is a coefficient of friction which is defined by the law Amontons-Coulomb [8]: 


$$
F_{m p}=k N
$$

where $N$-normal reaction force, $k$ - coefficient of friction, $F_{m p}$ - friction force.

The Amonton-Coulomb law (1) was originally formulated for homogeneous materials and did not consider the influence of the structure of the material. But if we assume that the law of friction is applicable at the level of the components of the composite structure, then the methods of mechanics of composite materials make it possible to predict the effective tribological characteristics of the composite.

The paper considers the contact problem for an inhomogeneous medium, the model of contact interaction of a fibrous composite with a tetragonal arrangement of fibers (Fig. 1). The periodicity cell is rectangular. At the interface fiber-matrix condition of strain compatibility and condition of perfect contact at the interface between steel-composite.

For an inhomogeneous medium it is assumed that the periodicity cell averaged field structural stress and strain correspond to the macroscopic.

The method of local approximation. The local approximation method uses the short-range effect in the interaction of inhomogeneities and is based on the principle of locality. The essence of the method is to replace the periodic problem with a boundary value problem for a domain containing a finite number of inclusions [1]:

$$
\begin{aligned}
& \sigma_{i j, j}(\vec{r})=0, \\
& \sigma_{i j}(\vec{r})=\lambda(\vec{r}) \varepsilon_{\alpha \alpha}(\vec{r}) \delta_{i j}+2 \mu(\vec{r}) \varepsilon_{i j}(\vec{r}), \\
& \varepsilon_{i j}(\vec{r})=\frac{1}{2}\left[u_{i, j}(\vec{r})+u_{j, i}(\vec{r})\right] .
\end{aligned}
$$

Elastic Lamé constants in the physical equations are piecewise-homogeneous periodic functions, and macrostresses will correspond to structural stresses at the boundary of the periodicity cell:

$$
\left.\sigma_{i j}(\vec{r})\right|_{\omega}=s_{i j} .
$$

This follows from the equivalence volume and surface conditions and averaging uniform stress distribution on the surface of the periodicity cell. Method uses a low-order effect, the periodicity of the lateral boundaries of the cell in the plane of contact is not moved. Matrix and fiber material are considered homogeneous and isotropic.

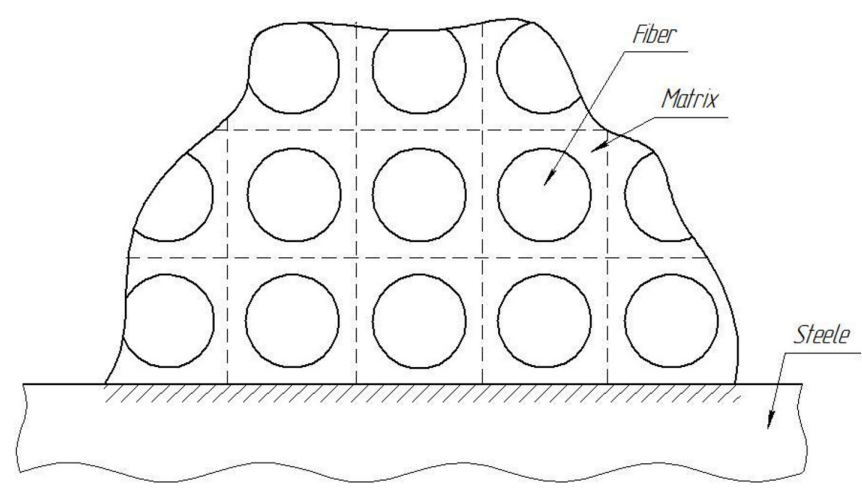

Fig. 1. Model of contact interaction of a unidirectional fibrous composite with an elastic deformable body 
Research Methodology. The following technique is used to determine the effective friction coefficients of composites. For this, a periodicity cell (Fig. 2) is allocated in the composite material, which is located at the interface between the steel support and the contact. At the upper boundary of the selected cell, compressive stresses are applied (Fig. 2) so that the fibrous composite material is pressed against the steel support and contact interaction occurs in the steel-composite friction pair. In two-dimensional modeling of the stress state in the steel-composite contact zone, a finite element mesh with four nodes (Plane 182) was used, as well as the ideal contact condition at the steel-composite interface. The contact stresses during the FEM analysis are determined for each edge adjacent to the steel-composite contact line of the final element on a rib belonging to the contact line. Using the law of friction (1) for the components of the structure of a unidirectional composite allows one to determine the friction force in individual sections of the contact line corresponding to the edges of the finite element mesh. Within the edge of the final element, contact interaction is carried out either for a steel-fiber pair or for a steel-matrix pair. The obtained contact stress elements, the frictional force is determined by the total:

$$
F_{m p}=\sum_{i=1}^{n} F_{m p}^{i}
$$

The law of friction (1) holds for a fibrous composite at a macroscopic level, then the friction force in a steel-composite pair can be expressed as follows:

$$
F_{m p}=k F_{N}=k \sigma_{y} \delta
$$

where $\sigma_{y}$ - preassigned stress; $\delta$ - contact size; $k$ - coefficient of friction of the composite material. The effective coefficient of friction of a unidirectional fibrous material with a tetragonal structure for a steel-composite pair can be obtained from relations (4) and (5):

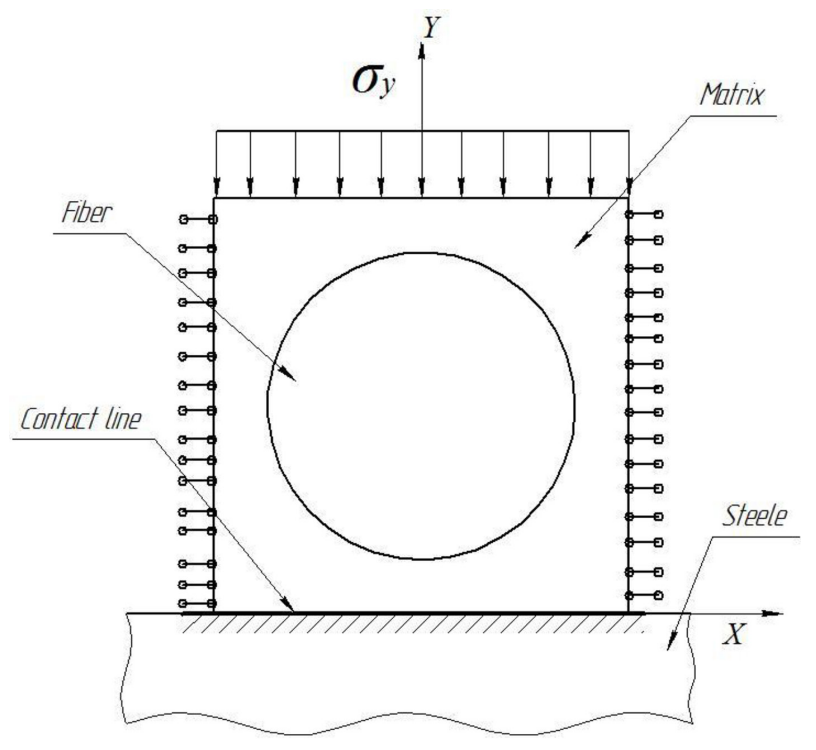

Fig. 2. The principle of locality in the problem of contact interaction of a unidirectional fibrous composite with a deformable body 


$$
k=\frac{\sum_{i=1}^{n} F_{m p}^{i}}{\sigma_{y} \delta} .
$$

The resulting ratio is significantly different from the recommended for evaluating the tribotechnical properties of composites mixtures:

$$
k=V_{1} k_{1}+V_{2} k_{2}
$$

where $V_{1}, V_{2}$ - volume fractions of fibers and matrix; $k_{1}, k_{2}$ - friction coefficients steel-fiber and steelmatrix.

\section{Results}

As the objects of modeling unidirectional fibrous polymer composite are used carbon fiber and fiberglass based on an epoxy matrix (Table 1). The cell size of the periodicity is taken equal to 6.28 microns.

Table 1. Elastic properties and coefficients of friction of materials

\begin{tabular}{|l|c|c|c|}
\hline \multicolumn{1}{|c|}{ Materials } & $\begin{array}{c}\text { Young's modulus, } \\
\text { GPa }\end{array}$ & Poisson's ratio & $\begin{array}{c}\text { Coefficient of } \\
\text { friction on steel }\end{array}$ \\
\hline Epoxy resins [9, 10] & 4 & 0,34 & 0.12 \\
\hline Carbon fiber VMN-4 [9, 11] & 270 & 0,28 & 0.15 \\
\hline Fiberglass C-Glass [9, 11] & 70 & 0,22 & 0.5 \\
\hline Steel $[9,11]$ & 200 & 0,25 & - \\
\hline
\end{tabular}

The fiberglass diameter is assumed to be $6 \mu \mathrm{m}$ in size, while the volume fraction of fiberglass in the fiberglass periodicity cells will be considered equal to $71.5 \%$. For carbon fiber, the fiber diameter will be 5.26 microns with a volume fraction of $55 \%$. The periodicity cell size is $6.28 \mu \mathrm{m}$.

At the upper boundary of the periodicity cell, stresses are set $\sigma_{y}=100 \mathrm{H} / \mathrm{M}^{2}$.

To account for the effect of wear on the friction coefficient in a pair of steel-composite simulated four tetragonal cell configurations in the contact zone. Figure 4 shows the breakdown of the contact zones into finite elements and the distribution of normal stresses relative to the steel-composite contact plane for a full-fledged periodicity cell (Fig. 3, a), as well as for cells with $25 \%$ wear (Fig. 3, b), 50\% (Fig. 3, c) and 75\% (Fig. 3, d).

Figures 4 and 5 shows the distribution of contact pressure for unidirectional fibrous composites: fiberglass reinforcement with a volume fraction of $71.5 \%$ (Fig. 4) and the carbon fiber reinforcement with a volume fraction of 55\% (Fig. 5).

The distribution of normal contact stresses has a significant heterogeneity even in the steel-matrix interaction (Fig. 4, a and 5, a), the presence of a more rigid inclusion in the form of glass or carbon fiber causes a change in structural stresses in the steel-matrix contact zone by $4 . .5$ times. When half the cell is worn (Fig. 4, c and 5, c), the contact stresses in the steel-fiber pair are distributed fairly evenly, and in the steel-matrix contact zone the stress level is much lower. Perhaps the most interesting are the 

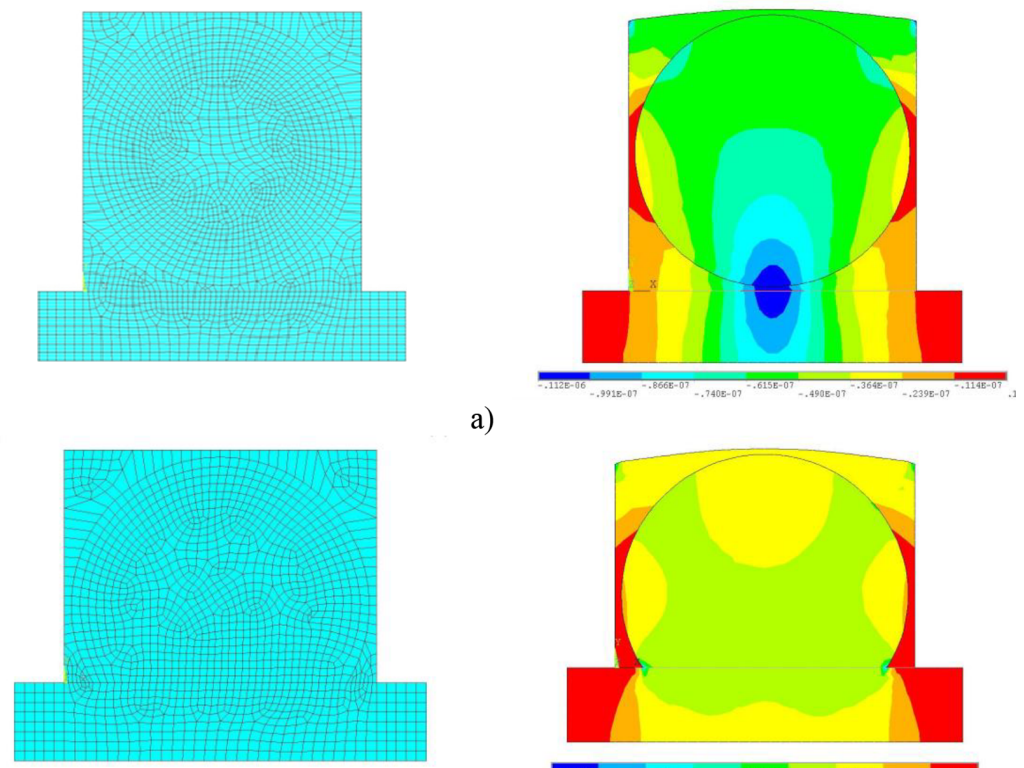

a)

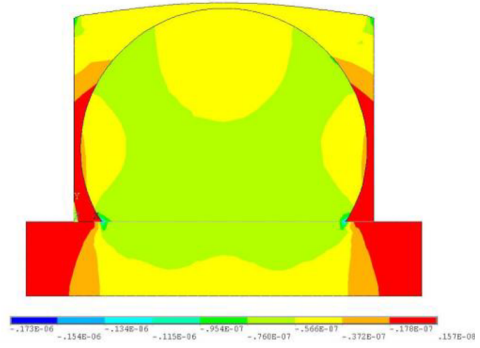

b)
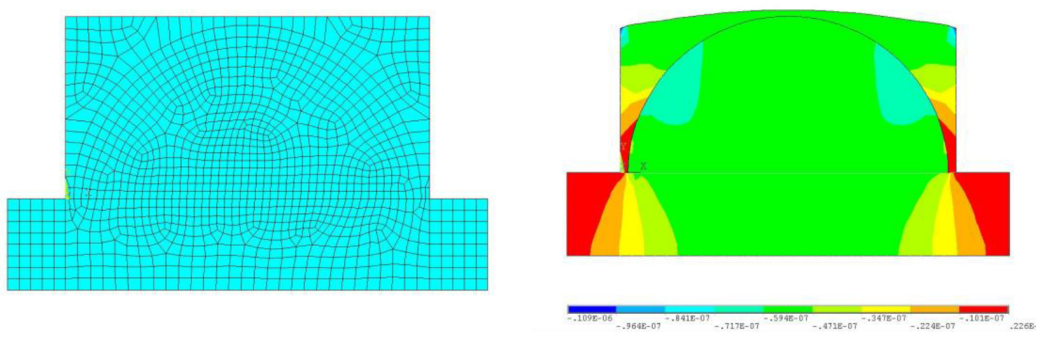

c)
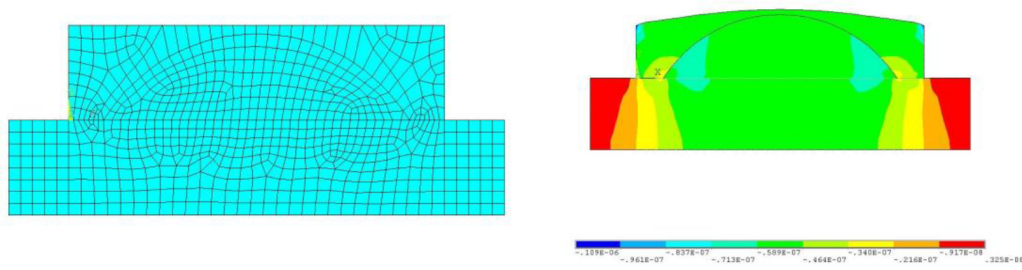

d)

Fig. 3. The mesh of finite elements and the field of normal stresses (MPa) unidirectional fiberglass with various wear: a) there is no wear, b) wear $25 \%$, c) wear $50 \%$, d) wear $75 \%$

stress distributions with wear by a quarter (Fig. 4, b and 5, b) and three quarters (Fig. 4, d and 5, d) of the tetragonal periodicity cell, since with an equal length of the steel-fiber or steel contact line -matrix, a qualitative difference in forms is observed. When a quarter of the cell is worn (Fig. 4, b and 5, b), the distribution of contact stresses is similar to the distribution at half wear (Fig. 4, c and 5, c), when almost uniform, the highest stresses arise in the fiber and insignificant stresses in the matrix. When the cell wears by three quarters (Fig. 4, d and 5, d), with a fairly uniform distribution of structural contact 


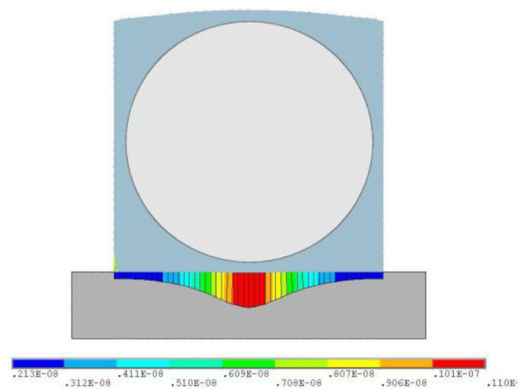

a)

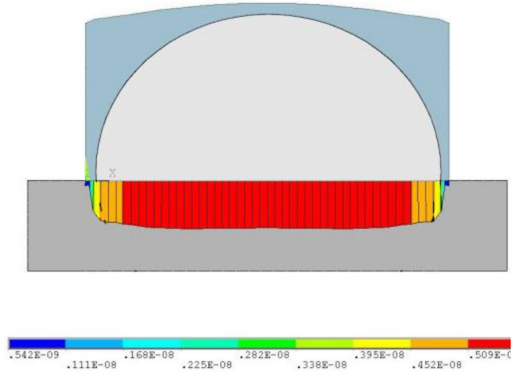

c)

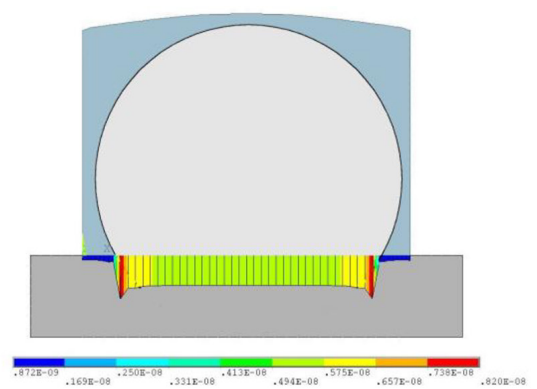

b)
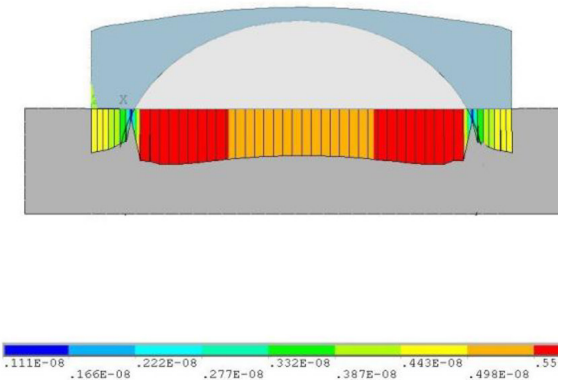

d)

Fig. 4. Contact stresses (MPa) in fiberglass with a fiber share of $71.5 \%$ : a) there is no wear, b) wear $25 \%$, c) wear $50 \%$, d) wear $75 \%$

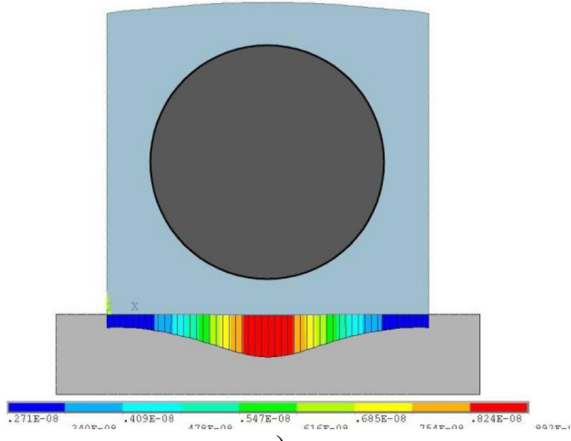

a)

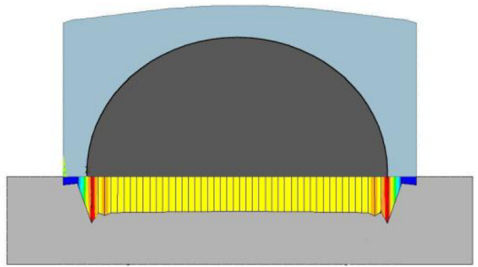

c)

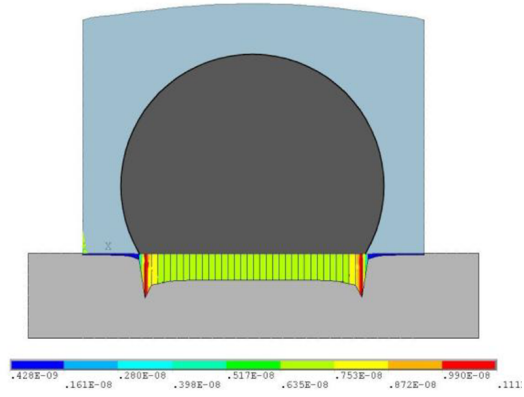

b)
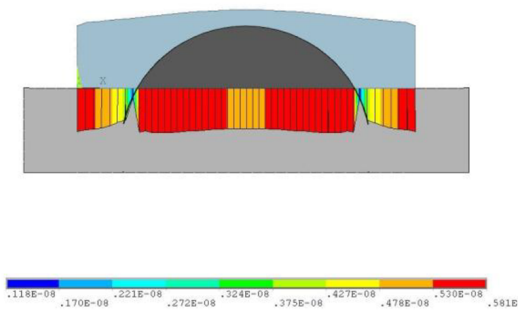

d)

Fig. 5. Contact stresses (MPa) in carbon fiber with a fiber fraction of 55\%: a) there is no wear, b) wear $25 \%$, c) wear $50 \%$, d) wear $75 \%$ 
Table 2. Results of calculating the effective coefficient of friction of a steel-composite pair

\begin{tabular}{|c|c|c|c|c|}
\hline \multirow{2}{*}{ Wear, \% } & \multicolumn{2}{|c|}{ Fiberglass friction coefficient } & \multicolumn{2}{c|}{ CFRP coefficient of friction } \\
\cline { 2 - 5 } & FEM analysis (6) & Rule mixture (7) & FEM analysis (6) & Rule mixture (7) \\
\hline 0 & 0.192 & 0.12 & 0.116 & 0.12 \\
\hline 25 & 0.246 & 0.427 & 0.165 & 0.14 \\
\hline 50 & 0.234 & 0.481 & 0.145 & 0.145 \\
\hline 75 & 0.207 & 0.427 & 0.103 & 0.14 \\
\hline
\end{tabular}

stresses in the fiber and the matrix, a fairly local unloading is observed in the vicinity of the contact point between the fiber and the matrix.

Table 2 presents the results of calculating the effective friction coefficient of unidirectional glass and carbon fiber tetragonal structures during numerical simulation using FEM analysis (6) and according to the rule of the mixture (7) for a steel-composite friction pair. The volume fraction of fiber in the composite is an invariable parameter and, when calculated according to formula (7), the amount of wear does not affect the result according to the rule of the mixture. So for fiberglass with a fiber volume fraction of $71.5 \%$, formula (7) gives an estimate of the friction coefficient of 0.392 , for carbon fiber with a fiber volume fraction of $55 \%$, the friction coefficient according to the mixture rule (7) is 0.137. In [12], it is recommended, instead of the volume fraction of fiber or matrix, to use the relative fraction of fiber or matrix in the steel-composite contact zone. The calculation results presented in Table 2 for the mixture rule were also performed using the relative fraction of the fiber or matrix content in the steel-composite contact zone.

As a result, the contact interaction problem for unidirectional fiber polymer composites of a tetragonal structure with a uniform elastic body was solved, the change in the effective friction coefficients for a steel-composite pair during wear, as well as the distribution field of normal and contact stresses in the structure components of the composite material, were studied, the main conclusions on work results:

1. The tribological properties of unidirectional fiber composites in the reinforcement plane substantially depend on the proportion of material wear. The rule of the mixture does not always allow us to evaluate the change in tribological characteristics with accuracy sufficient for practical purposes.

2. Tribological properties are determined by the structure of the inhomogeneous material in the contact zone and the corresponding distribution of structural stress fields. The rule of the mixture, even modified taking into account the relative fraction of fiber and matrix in the contact zone, does not allow this feature to be taken into account.

3. Using models of the mechanics of composites allows you to create a heterogeneous structure with an effective coefficient of friction, the value of which cannot be achieved at the level of the tribological properties of the individual components of the structure.

\section{References}

[1] Sokolkin Y.V., Tashkinov A.A. Deformation and Fracture Mechanics of Structurally Inhomogeneous Bodies, Moscow, Nauka, 1984, 115 p. (in Russian)

$$
-205-
$$


[2] Makarova E. Yu., Sokolkin Yu. V., Chekalkin A. A. Structural-Phenomenological Models for Predicting of the Elastic Properties for High-Pore Composites, Vestn. Samar. Gos. Tekhn. Univ., Ser. Fiz.-Mat. Nauki [J. Samara State Tech. Univ., Ser. Phys. Math. Sci.], 2010, 5, 276-279

[3] Sokolkin Yu.V., Chekalkin A.A., Babushkin A.V. Prediction of physical and mechanical properties of powder and reinforced with highstrength fibers of metallic materials. Izvestiya vysshikh uchebnykh zavedeniy. Tsvetnaya metallurgiya. Moscow, 1995, 2, 53-57.

[4] Golchin A., Simmons G.F., Glavatskih S., Prakash B. Tribological behaviour of polymeric materials in water-lubricated contacts, Proceedings of the Institution of Mechanical Engineers, Part J: Journal of Engineering Tribology, 2013, 1-16.

[5] Du Gang, Cai Chilan, Haobin Tian. The research on the effect of $\mathrm{SiO} 2$ and CF on the tensile and tribological properties of PI composite, Proceedings of the Institution of Mechanical Engineers, Part J: Journal of Engineering Tribology. 2015, 1-6.

[6] Christopher J Dyson, Martin Priest, Malcolm F. Fox, Bill Hopkins. The tribological behaviour of carbon fibre reinforced polyaryletherketones (PAEKs) through their glass transitions, Proceedings of the Institution of Mechanical Engineers, Part J: Journal of Engineering Tribology, 2015, 1-15.

[7] Liu Jian, Zhang Yongzhen, Du Sanming, Lu Fei. Effect of friction heat on tribological behaviors of Kevlar fabric composites filled with polytetrafluoroethene, Proceedings of the Institution of Mechanical Engineers, Part J: Journal of Engineering Tribology, 2015, 1-9.

[8] Kragel'skii I.V., Dobychin M.N., Kombalov V.S. Fundamentals of friction and wear calculations, Moscow, Mashinostroenie, 1977, 526 p. (in Russian)

[9] Vasiliev V. V., Protasov V. D., Bolotin V. V. Composite materials: Reference book, Moscow, Mashinostroenie, 1990, $512 \mathrm{p}$.

[10] Dzh. Lyubin. Handbook of composite materials, Moscow, Mashinostroenie, 1988, 448 p.

[11] Richardson M. Promyshlennye polimernye kompozicionnye, Moscow, Himiya, 1980. 472 p. London: EHplajd Sajens Pablisher, 1977.

[12] Kragel'skij I.V. Coefficients of friction. Reference manual, Moscow, MASHGIZ, 1962, 220 p. 